\title{
Multilevel Converters as a Utility Interface for Renewable Energy Systems
}

\author{
Leon M. Tolbert \\ The University of Tennessee \\ Electrical and Computer Engineering \\ 311 Ferris Hall \\ Knoxville, TN 37996-2100 \\ Phone: (865) 974-2881 \\ FAX: (865) 974-5483 \\ E-mail: tolbert@utk.edu
}

\author{
Fang Z. Peng \\ Oak Ridge National Laboratory \\ Engineering Technology Division \\ P.O. Box 2009 \\ Oak Ridge, TN 37831-8038 \\ Phone: (865) 576-7261 \\ FAX: (865) 241-6124 \\ E-mail: pengfz@ornl.gov
}

Keywords: multilevel converters, photovoltaics, fuel cells, utility interface, power quality

\section{INTRODUCTION}

Electric power production in the $21^{\text {st }}$ Century will see dramatic changes in both the physical infrastructure and the control and information infrastructure. A shift will take place from a relatively few large, concentrated generation centers and the transmission of electricity over mostly a high voltage ac grid (Fig. 1) to a more diverse and dispersed generation infrastructure that also has a higher percentage of dc transmission lines (Fig. 2) [1].

In the United States, generation capacity has not kept up with power demands, as over the last decade the reserve margins declined from $22 \%$ in 1990 to $16 \%$ in 1997 . This declining margin trend is expected to continue over the next decade partly because of the uncertainty of how the future deregulated electrical environment will function. Less reserve margins will lead to less peaking capacity on highdemand days and more volatile energy prices [2]. This change in a physical infrastructure combined with a more deregulated electric power industry will result in more parties generating power - or distributed generation.

Some of the distributed generation power sources that are expected to increase greatly their market share of the total power produced in the United States and abroad include renewable energy sources such as photovoltaics, wind, low-head hydro, and geothermal [3]. Fuel cell technology is also nearing the development point where it could start to supply a significant share of the power needs [4]. The advent of high power electronic modules has also encouraged the use of more $\mathrm{dc}$ transmission and made the prospects of interfacing dc power sources such as fuel cells and photovoltaics more easily attainable. A modular, scalable power electronics technology that is ideal for these types of utility applications is the transformerless multilevel converter [5].

Multilevel inverter structures have been developed to overcome shortcomings in solid-state switching device ratings so that they can be applied to high-voltage electrical systems. The multilevel voltage source inverters' unique structure allows them to reach high voltages with low harmonics without the use of transformers. This makes these unique power electronics topologies suitable for flexible ac transmission systems (FACTS) and custom power applications $[6,7]$. The use of a multilevel converter to control the frequency, voltage output (including phase angle), and real and reactive power flow at a dc/ac interface provides significant opportunities in the control of distributed power systems.

The general function of the multilevel inverter is to synthesize a desired ac voltage from several levels of dc voltages. For this reason, multilevel inverters are ideal for connecting either in series or in parallel an ac grid with renewable energy sources such as photovoltaics or fuel cells or with energy storage devices such as capacitors or batteries. Additional applications of multilevel converters include such uses as medium voltage adjustable speed motor drives, static var compensation, dynamic voltage restoration, harmonic filtering, or for a high voltage $\mathrm{dc}$ back-to-back intertie.

Because distributed power sources are expected to become increasingly prevalent in the near future, the use of a multilevel converter to control the frequency and voltage output (including phase angle) from renewable energy sources will provide significant advantages because of its fast response and autonomous control. Additionally, multilevel converters can also control the real and reactive power flow from a utility connected renewable energy source. These power electronic topologies are attractive for continuous control of system dynamic behavior and to reduce power quality problems such as voltage harmonics, voltage imbalance, or sags [8-10].

With a capacitance connected in parallel with the renewable energy source, a multilevel converter can provide static var compensation even when there is no output power from the photovoltaic or fuel cell energy source. With banks of batteries or large capacitors on the dc bus, the multilevel converter can provide significant ridethrough capability for voltage sags or load swings experienced at the utility interface connection. 


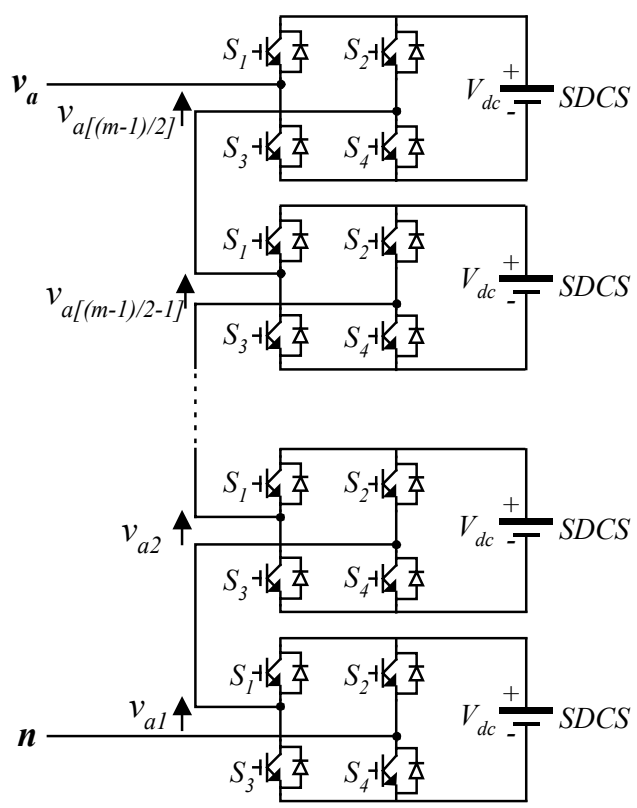

Fig. 1. Single-phase structure of a multilevel cascaded H-bridges inverter.

\section{CASCADED H-BRIDGES MUlTILEVEL INVERTER}

One multilevel converter topology incorporates cascaded single-phase H-bridges with separate dc sources (SDCSs). This requirement makes renewable energy sources such as fuel cells or photovoltaics a natural choice for the isolated dc voltage sources needed for the cascade inverter. Fig. 1 shows a single-phase structure of an $m$-level cascade inverter. Each SDCS is connected to a singlephase full-bridge, or H-bridge, inverter. Each inverter level can generate three different voltage outputs, $+V_{d c}, 0$, and $-V_{d c}$ by connecting the dc source to the ac output by different combinations of the four switches, $S_{1}, S_{2}, S_{3}$, and $S_{4}$. To obtain $+V_{d c}$, switches $S_{1}$ and $S_{4}$ are turned on. Turning on switches $S_{2}$ and $S_{3}$ yields $-V_{d c}$. By turning on $S_{l}$ and $S_{2}$ or $S_{3}$ and $S_{4}$, the output voltage is 0 .

The ac outputs of each of the different full-bridge inverter levels are connected in series such that the synthesized voltage waveform is the sum of the inverter outputs. The number of output phase voltage levels $m$ in a cascade inverter is defined by $m=2 s+1$, where $s$ is the number of separate dc sources (photovoltaic modules or fuel cells). An example phase voltage waveform for an 11level cascaded H-bridge inverter with 5 SDCSs and 5 full bridges is shown in Fig. 2. The phase voltage $v_{a n}=v_{a 1}+v_{a 2}$ $+v_{a 3}+v_{a 4}+v_{a 5}$.

The conducting angles, $\theta_{1}, \theta_{2}, \ldots, \theta_{s}$, can be chosen such that the voltage total harmonic distortion is a minimum. Normally, these angles are chosen so as to cancel the predominant lower frequency harmonics. For the 11-level case in Fig. 2, the 5th, 7th, 11th, and 13th harmonics can be eliminated with the appropriate choice of the conducting angles. One degree of freedom is used so

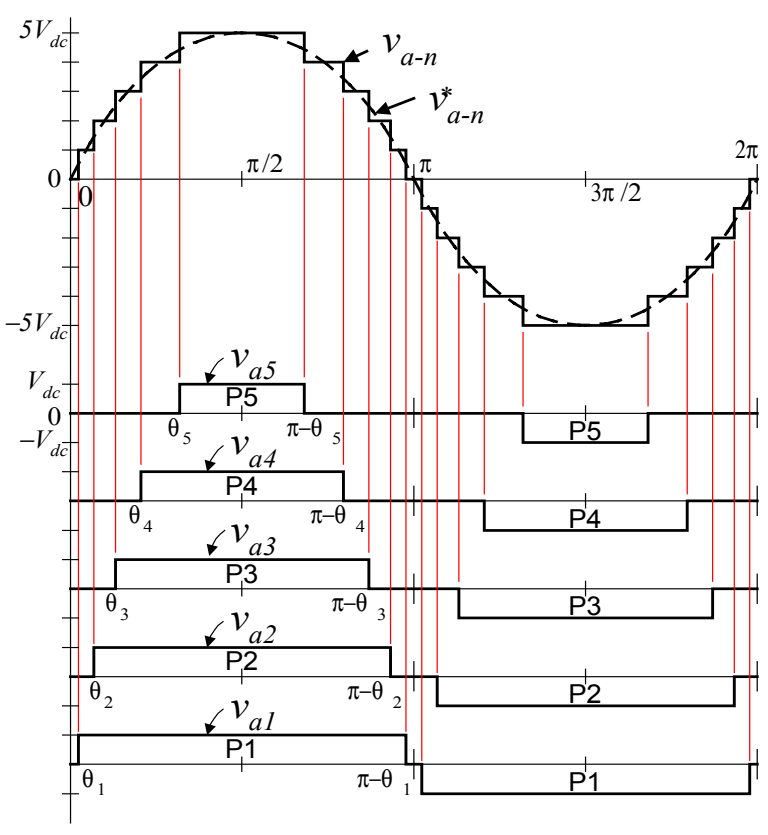

Fig. 2. Waveforms and switching method of the 11-level cascade inverter.

that the magnitude of the fundamental waveform corresponds to the reference waveform's amplitude or modulation index [11].

From Fig. 2, note that the duty cycle for each of the voltage levels is different. If this same pattern of duty cycles was used continuously, then the level-1 voltage source would be required to generate much more power than the level-5 voltage source. However, by using a switching pattern-swapping scheme among the various levels every $1 / 2$ cycle, as shown in Fig. 3, all the energy sources will be equally used.

Three-phase cascaded inverters can be connected in wye as shown in Fig. 4 or in delta [10]. One of the main advantages of the cascaded inverter is that the series of $\mathrm{H}$ bridges makes for modularized layout and packaging. This will enable the manufacturing process to be done more quickly and inexpensively. Also, redundant voltage levels can be included in an application design so that the inverter can still operate even with the loss of one level. This enables the multilevel inverter to continue to function even when there is a problem with one of the dc sources or with one of the power electronics devices that make up the $\mathrm{H}$ bridge.

\section{EXPERIMENTAL PROTOTYPE}

A $10 \mathrm{~kW}$ prototype three-phase 11-level wyeconnected cascaded inverter has been built using insulated gate bipolar transistors (IGBT's) as the main switching devices. Fig. 5 shows experimental output voltage and current waveforms for the SDCS-fed inverter prototype driving a three-phase induction motor using the aforementioned fundamental frequency switching scheme. 


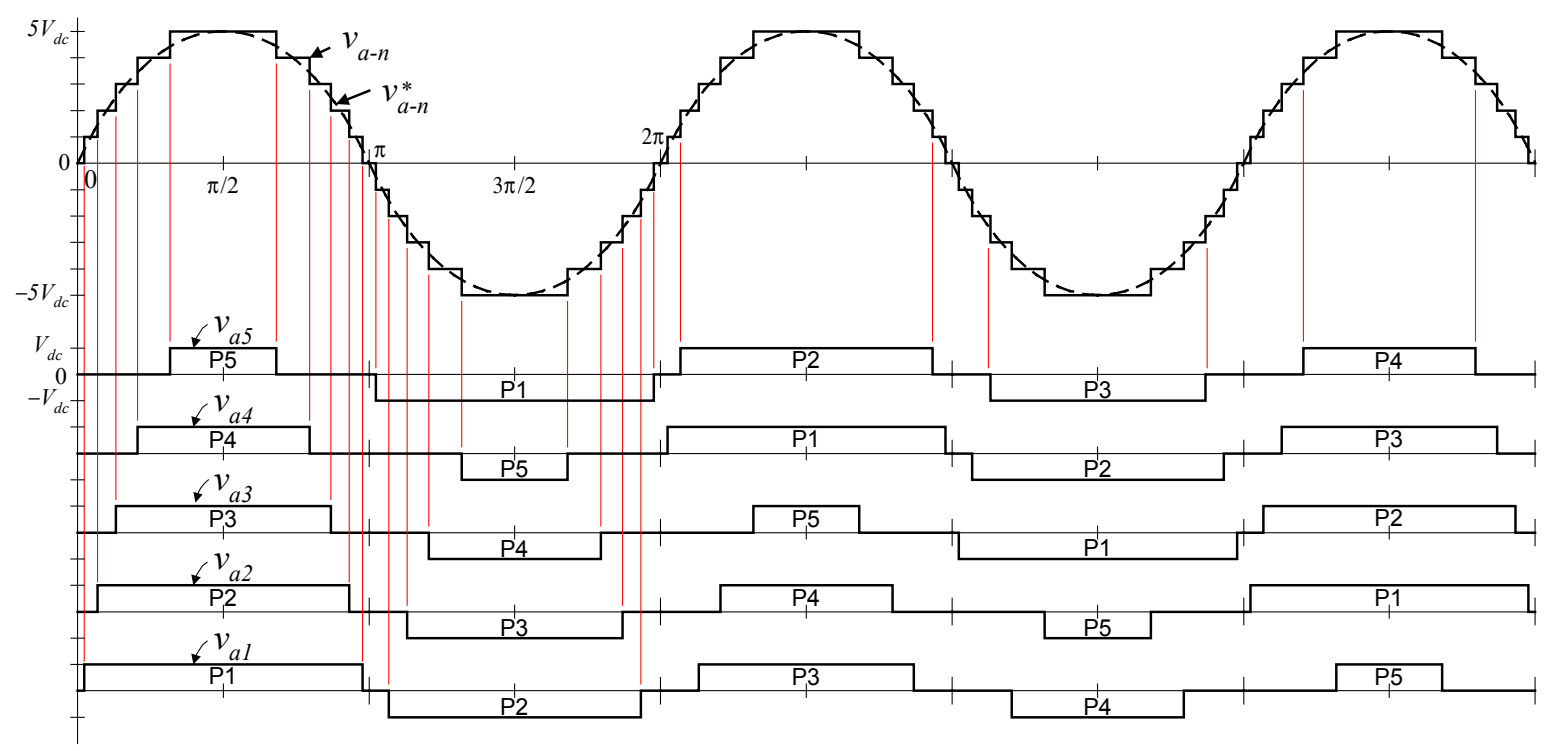

Fig. 3. Switching pattern swapping of the 11-level cascade inverter for balancing battery charge.

Both the line-line voltage and current are almost sinusoidal without the use of any output filters on the experimental converter. Electromagnetic interference (EMI) and common-mode voltage are also inherently less because of the low switching frequency, low $\mathrm{dV} / \mathrm{dt}$ (21 times less than a two-level drive), and sinusoidal voltage output [11].

Multilevel converters can also be controlled with various types of multilevel pulse width modulation (PWM) schemes if the application warrants such use. The combination of multiple steps and PWM enables a great deal of flexibility in the desired output waveform [12].

A pulse rotation technique similar to the one used for fundamental frequency switching of cascade inverters can be used when a PWM output voltage waveform is desired,

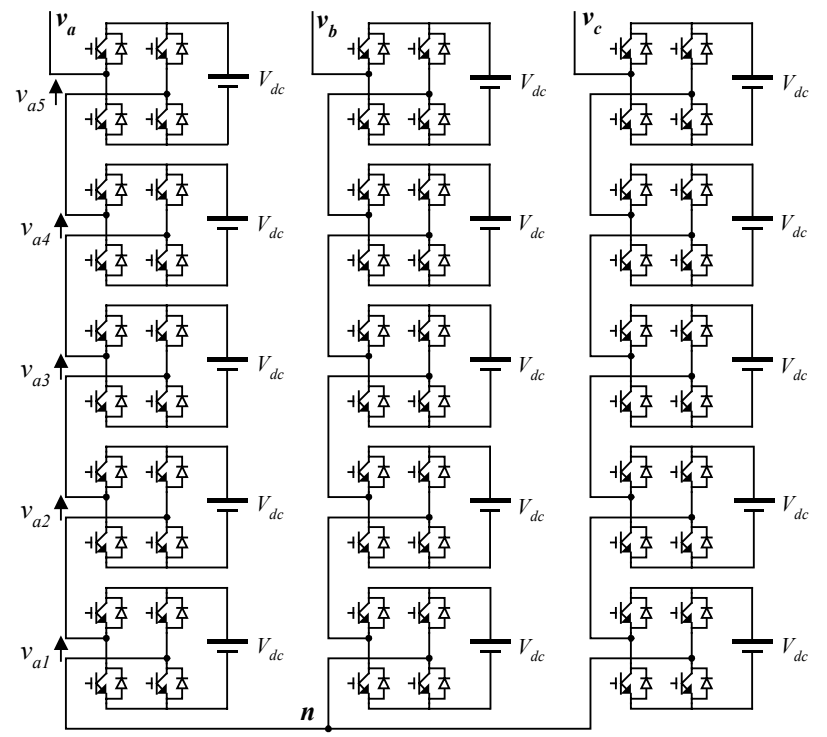

Fig. 4. 11-level wye-configured cascaded inverter. which is the case at low modulation indices. The effect is that the output waveform can have a high switching frequency but the individual levels can still switch at a constant switching frequency of $60 \mathrm{~Hz}$ if desired [13].

Example PWM pulses for this type of pulse rotation control are shown in Fig. 6. Pulses $\left(V_{a l}, V_{a 2}\right.$, and $\left.V_{a 3}\right)$ are shown for three of the five H-bridges that compose the $a$ phase of the inverter. The line-neutral voltage waveform $V_{a n}$ is composed of the sum of the pulses from all five Hbridges. While the switching frequency of each individual $\mathrm{H}$-bridge is kept constant at $60 \mathrm{~Hz}$, the effective switching frequency of the phase-neutral voltage is $300 \mathrm{~Hz}$. This technique allows a multilevel cascaded inverter to achieve a quality PWM output waveform at low modulation indices without resorting to high frequency switching [13].

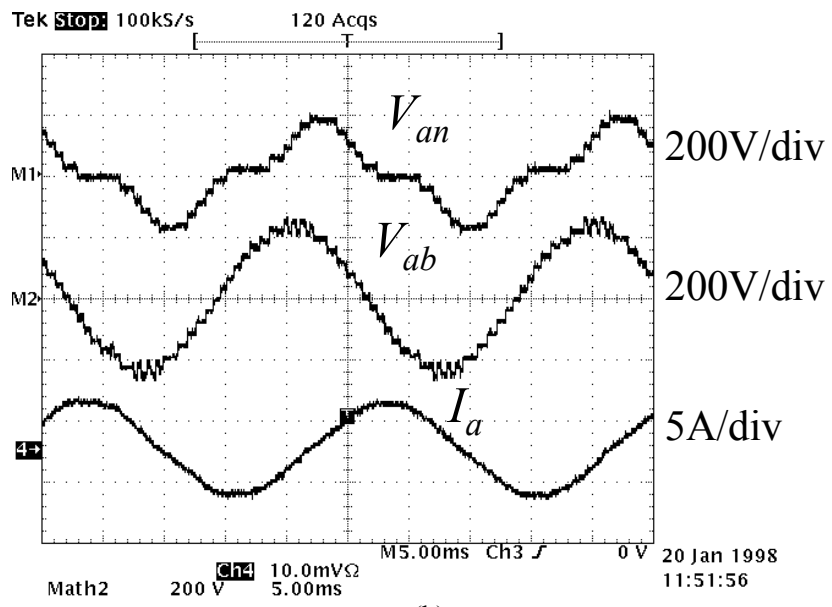

(b)

Fig. 5. Experimental waveforms of a cascade inverter prototype driving an induction motor at $80 \%$ rated speed. 


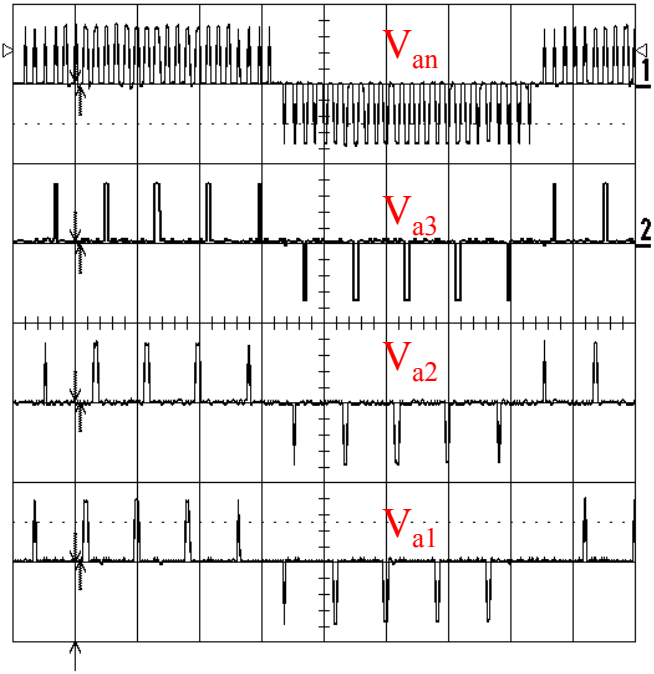

Fig. 6. Pulse rotation in an 11-level prototype cascade inverter.

\section{OTHER MULTILEVEL TOPOLOGIES}

The two other main multilevel converter topologies include the diode-clamped converter and the flying capacitor converter. Each of the three phases for either of these inverters shares a common dc bus, which has been subdivided into several levels as shown for a diode-clamped inverter in Fig. 7. These topologies are ideal for high voltage dc back-to-back interties or as adjustable speed drives $[5,14]$.

\section{Advantages of Multilevel Converters}

Multilevel converters have been shown to have the following advantages:

1. They are suitable for medium to high power applications.

2. They are an ideal interface between a utility and renewable energy sources such as photovoltaics or fuel cells.

3. Their efficiency is very high $(>98 \%)$ because of the minimum switching frequency.

4. They can improve the power quality and dynamic stability for utility systems.

5. Switching stress and EMI are low.

6. Because of their modular and simple structure, they can be stacked up to an almost unlimited number of levels.

\section{References}

[1] J. D. Leeper, J. T. Barich, "Technology for Distributed Generation in a Global Market Place," Proceedings of the American Power Conference, 1998, pp. 33-36.

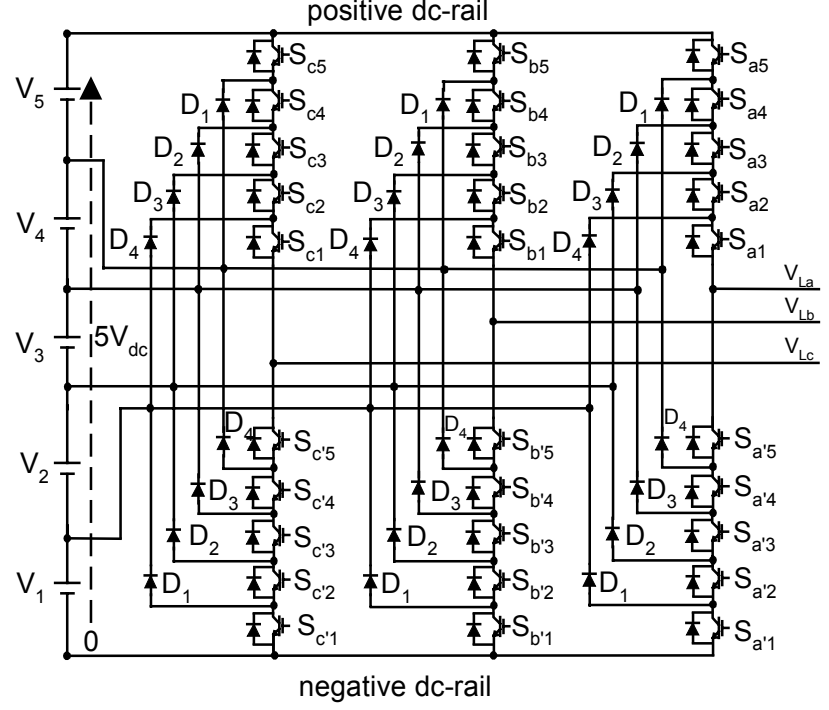

Fig. 7. Three-phase 6-level diode-clamped inverter structure.

[2] E. Hirst, S. Hadley, "Maintaining Generation Adequacy in a Restructuring U.S. Electricity Industry," Oak Ridge National Laboratory for the U.S. Environmental Protection Agency, ORNL/CON-472, October 1999.

[3] R. Hill, "Grid Connected Solar PV," IEE Colloquium on Developments in Photovoltaic Electricity Production, March 1997.

[4] M. Hsu, D. Nathanson, R. Goldstein, "Ultra-high Efficiency Fuel Cell/Gas Turbine System for Distributed Generation," Proceedings of the American Power Conference, 1997, pp. 559-561.

[5] J. S. Lai, F. Z. Peng, "Multilevel Converters - A New Breed of Power Converters," IEEE Transactions on Industry Applications, vol. 32, no. 3, May/June 1996, pp. 509-517.

[6] L. Gyugi, "Dynamic Compensation of AC Transmission Lines by Solid-State Synchronous Voltage Sources," IEEE Transactions on Power Delivery, vol. 9, no. 2, April 1994, pp. 904-911.

[7] A. van Zyl, J. H. R. Enslin, R. Spee, "A New Unified Approach to Power Quality Management," IEEE Transactions on Power Electronics, vol. 11, no. 5, Sept. 1996, pp. 691-697.

[8] F. Z. Peng, J. W. McKeever, D. J. Adams, "Cascade Multilevel Inverters for Utility Applications," Proc. of the Industrial Electronics, Control and Instrumentation Conference (IECON), 1997, pp. 437-442.

[9] F. Z. Peng, J. W. McKeever, D. J. Adams, "A Power Line Conditioner Using Cascade Multilevel Inverters for Distribution Systems," IEEE Transactions on Industry Applications, vol. 34, no. 6, Nov./Dec. 1998, pp. 1293-1298.

[10]F. Z. Peng, J. S. Lai, "Dynamic Performance and Control of a Static Var Generator Using Multilevel Inverters," IEEE Transactions on Industry Applications, vol. 33, no. 3, May/June 1997, pp. 748-755.

[11]L. M. Tolbert, F. Z. Peng, T. G. Habetler, "Multilevel Converters for Large Electric Drives," IEEE Transactions on Industry Applications, vol. 35, no. 1, Jan./Feb. 1999, pp. 36-44.

[12]L. M. Tolbert, T. G. Habetler, "Novel Multilevel Inverter CarrierBased PWM Methods," IEEE Transactions on Industry Applications, vol. 35 , no. 5, Sept./Oct. 1999, pp. 1098-1107.

[13]L. M. Tolbert, F. Z. Peng, T. G. Habetler, "Multilevel PWM Methods at Low Modulation Indexes," IEEE Applied Power Electronics Conference, Dallas, Texas, March 14-18, 1999, pp. 1032-1039.

[14]L. M. Tolbert, F. Z. Peng, T. G. Habetler, "A Multilevel ConverterBased Universal Power Conditioner," IEEE Transactions on Industry Applications, vol. 36, no. 2, March/April 2000. 